\title{
A snow algal community on Akkem glacier in the Russian Altai mountains
}

\author{
Nozomu TAKEUCHI, ${ }^{*}$ Jun UETAKE, ${ }^{2}$ Koji FUJITA, ${ }^{3}$ Vladimir B. AIZEN, ${ }^{4}$ \\ Stanislav D. NIKITIN ${ }^{5}$ \\ ${ }^{1}$ Research Institute for Humanity and Nature, Takashima-cho 335, Kyoto 602-0878, Japan \\ E-mail: ntakeuch@faculty.chiba-u.jp \\ ${ }^{2}$ Tokyo Institute of Technology, Ookayama 1-21-2, Meguro-ku, Tokyo, 152-8551, Japan \\ ${ }^{3}$ Graduate School of Environmental Studies, Nagoya University, Nagoya 464-8601, Japan \\ ${ }^{4}$ College of Mines and Earth Resources, PO Box 443025, University of Idaho, Moscow, ID 83844-3025, USA \\ ${ }^{5}$ Glacio-Climatological Laboratory, Tomsk State University, 36 Lenina Street, 634050 Tomsk, Russia
}

\begin{abstract}
Snow algae are cold-tolerant algae growing on snow and ice and have been reported on glaciers in many parts of the world. Blooms of snow algae can reduce the surface albedo of snow and ice and significantly affect their melting. In addition, snow algae found in ice cores can be potential indicators of the paleo-environment, making them of great interest both to the biology and the geophysics of glaciers. A snow algal community was investigated in 2002 and 2003 on Akkem glacier in the Russian Altai mountains, where no information on its biological community has previously been available. Five species of snow algae including green algae and cyanobacteria were observed on the glacier. Red snow due to a bloom of algae (Chloromonas sp.) was visually apparent in the snow area during our study periods. The total algal cell-volume biomass on the glacier ranged from 97 to $1156 \mu \mathrm{L} \mathrm{m}^{-2}$, which is equivalent to that reported previously on glaciers in the Himalaya and Alaska. The community structure showed that Mesotaenium berggrenii and/or Ancylonema nordenskioeldii, which are common species on glaciers in the Northern Hemisphere, were dominant in the ice area, while Chloromonas sp. was dominant in the snow area. Such community structures are similar to those on Alaskan and Arctic glaciers but differ from those on Himalayan and Tibetan glaciers, even though the Altai mountains are geographically closer to the Himalaya and Tibet than to Alaska. The difference in algal communities between the Altaic and other glaciers is discussed together with physical and chemical conditions affecting the algae.
\end{abstract}

\section{INTRODUCTION}

Although snow algae have been well studied taxonomically and physiologically on snowfields (e.g. Hoham and Duval, 2001), ecological information about them is still limited, in particular on glaciers. Snow algae sustain cold-tolerant animal and bacterial communities on glaciers. These organisms form very simple and closed ecosystems on glaciers (e.g. Kohshima, 1987, 1994; Hoham and Duval, 2001). Snow algae and such biological communities vary among glaciers in different geographical locations. For example, the biomass of snow algae is more abundant on glaciers in the Himalaya and Alaska than in Patagonia, and their community structures also differ among glaciers in these regions (Takeuchi and Kohshima, 2004). These differences are likely due to physical and/or chemical conditions on the glaciers as well as to the dispersal range of each species. Such geographical variations are valuable to our understanding of glacial ecology. On Asian glaciers, biological communities including snow algae and bacteria are particularly diverse and abundant compared with those on glaciers in other parts of the world (Christner and others, 2000; Takeuchi and Kohshima, 2004). Thus, glaciers in Asian mountains are of great interest to studies of glacial biology. However, information on Asian snow algae and

*Present address: Graduate School of Science and Technology, Chiba University, Inage-ku, Chiba 263-8522, Japan. biological communities remains limited. For example, there is no information on the Altai mountains at the northern end of the mountainous region of central Asia (Fig. 1).

The ecology of snow algae is important not only for the biology but also for the geophysics of glaciers in terms of its impact on surface albedo and ice-core studies. Organic matter derived from snow algae (cryoconite) can accumulate on glacial surfaces, leading to changes in their surface albedo (e.g. Kohshima and others, 1993; Thomas and Duval, 1995; Takeuchi and others, 2001c). A reduction in surface albedo increases the solar radiation absorbed by the glacial surface, thus accelerating glacial melting, and highlighting a feedback mechanism by which snow algae and cryoconite might possibly affect the heat budget and mass balance of glaciers. Moreover, since the growth of snow algae depends on physical and chemical conditions on the glacial surface, those algae found in ice cores can be expected to constitute a new indicator for interpreting past environments (e.g. Yoshimura and others, 2000). Accordingly, the ecology of snow algae is of great significance to glacial geophysics.

In this paper, we aim to describe a snow algal community on an Altaic glacier (Akkem glacier in the Russian Altai mountains). The samples of snow algae were collected from several sites on the glacier and were qualitatively analyzed. The amount of cryoconite was also measured. Our results were then compared with those from other glaciers across the world. The difference in algal communities is discussed in terms of geographical differences among the regions. 


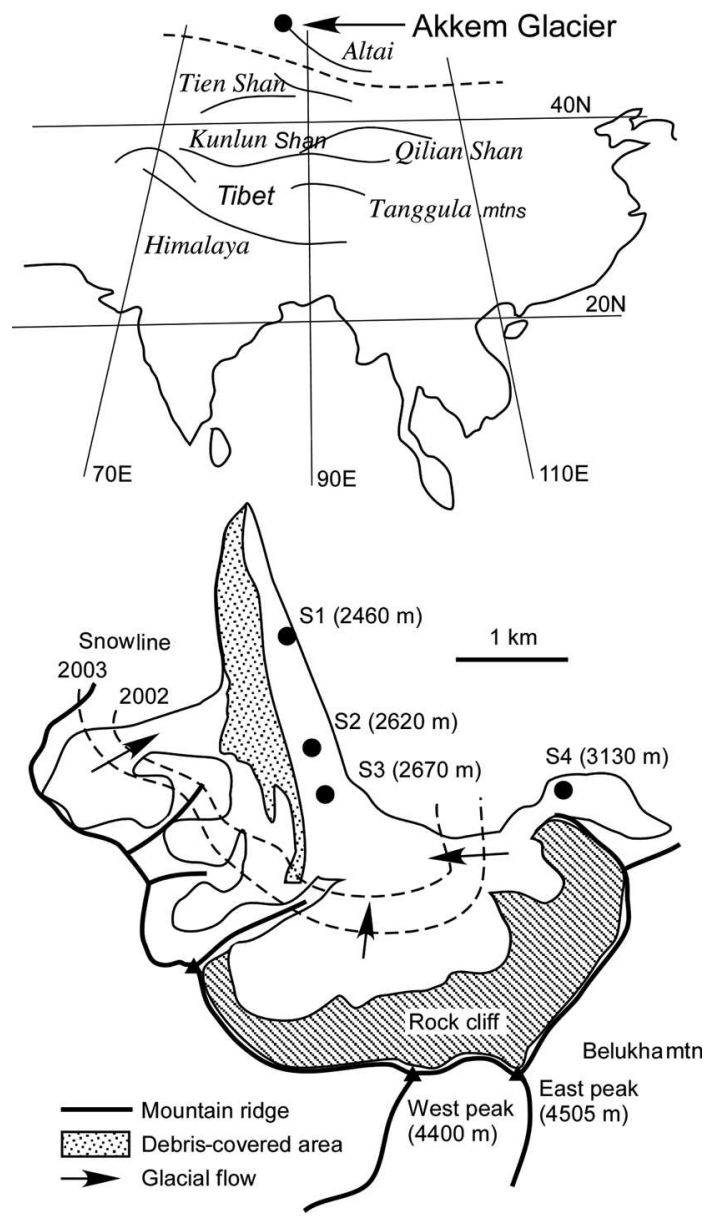

Fig. 1. Location of Akkem glacier in the Altai mountains, Russia, and map of the glacier showing sites of sample collection. The dotted line on the upper map is the geographical boundary of the snow algal community (see discussion).

\section{STUDY SITE AND METHODS}

Our research was carried out on Akkem glacier $\left(49^{\circ} 51^{\prime} \mathrm{N}\right.$, $86^{\circ} 33^{\prime} \mathrm{E}$ ) during July 2002 and July 2003. The Altai mountains, located in the central part of the Eurasian continent, extend from western Siberia to the Gobi Desert over a length of approximately $2000 \mathrm{~km}$ (Fig. 1). The glacier flows from the north at Belukha mountain, which is the highest peak in the Altai mountains $(4505 \mathrm{~m}$ a.s.l. at the summit) to the south down to its terminus at about 2200 ma.s.l. (Figs 1 and 2). Between the glacier and the summit of Belukha mountain, there is a rock cliff where avalanches frequently occur. Snow from those avalanches accumulates on the upper part of the glacier.

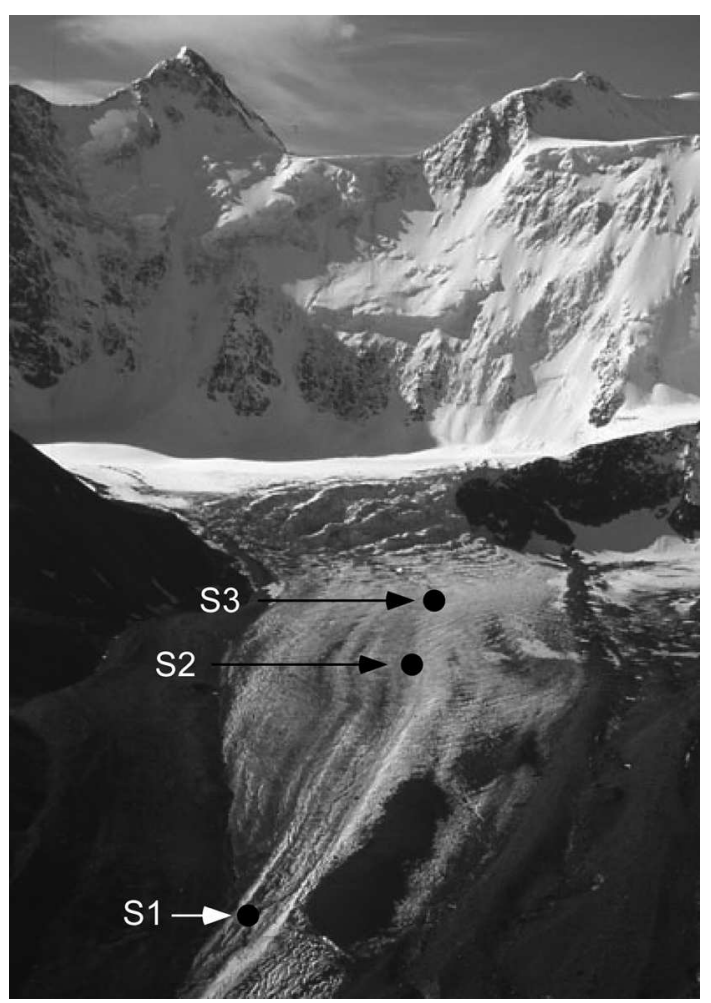

Fig. 2. Photograph of Akkem glacier and Belukha mountain, taken from a helicopter north of the glacier. Locations of sampling sites (S1-S3) are shown.

Collections of surface ice/snow were carried out at four sites, ranging in altitude from 2460 to $3130 \mathrm{~m}$ (S1-S4; Fig. 1). The sampling site is described in Table 1. Samples at site S1 were collected twice, on 11 July 2002 and 23 July 2003. Samples at sites S2, S3 and S4 were collected on 11 July 2002, 23 July 2003 and 15 July 2002, respectively. The snowline was at approximately $2900 \mathrm{~m}$ a.s.l. in July 2002 and $3000 \mathrm{~m}$ in July 2003. The surface condition of the sampling sites ranged from snow at the upper site (S4) to bare ice at the lower three sites (S1-S3). Red snow was visually apparent in both 2002 and 2003 in the snow area around 2900-3200 ma.s.I., including at S4. The pH and electrical conductivity (EC) for glacial meltwater were measured in situ with a portable $\mathrm{pH} /$ Conductivity Meter (Cyberscan PC300, Eutech Instruments Pte Ltd, USA). The $\mathrm{pH}$ ranged from 2.87 to 5.20 , and the EC ranged from 1.05 to $2.20 \mu \mathrm{S} \mathrm{cm}^{-1}$ (Table 1 ).

To quantify the algal community on the glacial surface, surface ice/snow was collected with a stainless-steel scoop $(1-2 \mathrm{~cm}$ in depth). The collected area on the surface was

Table 1. Description of sampling sites

\begin{tabular}{|c|c|c|c|c|c|}
\hline Site (year) & Sampling date & $\begin{array}{l}\text { Elevation } \\
\text { ma.s.l. }\end{array}$ & Surface condition & $\mathrm{pH}$ & $\begin{array}{l}\text { Electrical conductivity } \\
\qquad \mu \mathrm{S} \mathrm{cm}^{-1}\end{array}$ \\
\hline S1 (2002) & 11 July 2002 & 2460 & Ice & $4.52-5.11$ & $1.05-1.94$ \\
\hline S1 (2003) & 23 July 2003 & 2460 & Ice & $4.46-5.20$ & $1.14-1.32$ \\
\hline S2 (2002) & 11 July 2002 & 2620 & Ice & $4.04-4.84$ & $1.15-1.66$ \\
\hline S3 (2003) & 23 July 2003 & 2670 & Ice & $2.87-4.13$ & $1.28-2.20$ \\
\hline S4 (2002) & 18 July 2002 & 3130 & Wet snow & No data & No data \\
\hline
\end{tabular}



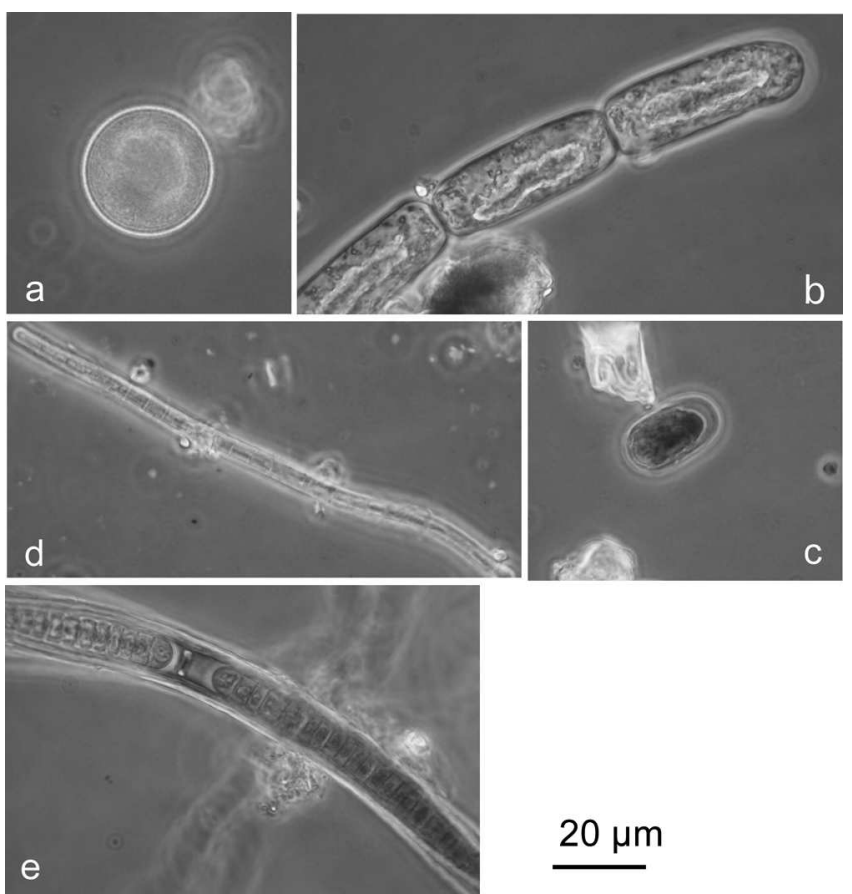

Fig. 3. Photographs of the snow algae observed on Akkem glacier: (a) Chloromonas sp.; (b) Ancylonema nordenskioeldii; (c) Mesotaenium berggrenii; (d) Oscillatoriaceae cyanobacterium; and (e) Calothrix parietina. All photographs were taken with a phasecontrast microscope. All samples were stored at $-10^{\circ} \mathrm{C}$ before microscopy, so some cell structure may be broken.

measured to calculate the amount of algal volume biomass per unit area. The collected samples were melted and then immediately preserved as a $3 \%$ formalin solution in clean $100 \mathrm{~mL}$ polyethylene bottles. These formalin samples were used for counting cell concentration. Although the fine structure of the algae might be lost by formalin, they could still be counted under a microscope. For identification of algal species, other samples were collected and kept frozen in a cooler. All samples were transported to the Research Institute for Humanity and Nature in Kyoto, Japan. The frozen samples were kept at $-10^{\circ} \mathrm{C}$ in a freezer.

The algal biomass of each site was represented by the cell number per unit of water volume and by the algal volume per unit area. Cell counts and estimations of cell volume were conducted using an optical microscope (Nikon E600). The samples were stained with $0.5 \%$ erythrosine $(0.1 \mathrm{~mL}$ was added to $3 \mathrm{~mL}$ of each sample) and ultrasonicated for 5 min to loosen sedimentary particles. 50-1000 $\mu \mathrm{L}$ of the sample water was filtered through a hydrophilized membrane filter (pore size $0.4 \mu \mathrm{m}$, Millipore JHWP01300), which became transparent with water, and the number of algae on the filter was counted (one to three lines on the filter). The count was taken three to six times on each sample. From the mean results and filtered sample water, the cell concentration (cells $\mathrm{mL}^{-1}$ ) of the sample was obtained. Mean cell volume was calculated from the nearest geometrical approximations from dimensions measured on 50-100 individual cells (Reynolds, 1984). Total algal biomass was estimated by adding up the values obtained from multiplying algal concentrations by the mean cell volume. These calculations were done for each species at each site. To obtain the spatial biomass at each site, the total biomass was represented as the cell volume per unit area of glacial

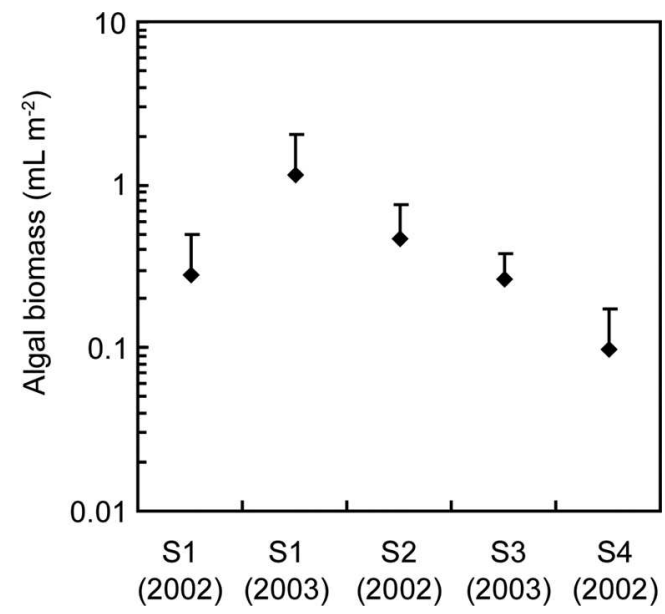

Fig. 4. Variations in total cell volume biomass among collection sites on Akkem glacier. Error bars indicate standard deviation. Numbers in parentheses show year of collection.

surface $\left(\mu \mathrm{L} \mathrm{m}^{-2}\right)$. Community structure was represented by the mean proportion of each species in five samples to the total algal volume at each sampling point.

To measure the amount and organic matter content of cryoconite on the glacial surface, ice/snow from the surface layer (approximately $15 \times 15 \mathrm{~cm}$ in area and $1-3 \mathrm{~cm}$ in depth, roughly $50-100 \mathrm{~mL}$ in water volume) was collected with a stainless-steel scoop. Five samples were collected from randomly selected surfaces at each study site. The collection area on the surface was measured to calculate the amount of cryoconite per unit area. The collected samples were melted and preserved as a $3 \%$ formalin solution in $100 \mathrm{~mL}$ clean polyethylene bottles to fix biological activity. In the laboratory, the samples were dried $\left(65^{\circ} \mathrm{C}, 24\right.$ hours $)$ in pre-weighed crucibles. The amount of cryoconite per unit area of the glacier was obtained based on the dry weight and sampling area. The dried samples were then combusted for 1 hour at $1000^{\circ} \mathrm{C}$ in an electric furnace and weighed again. The amount of organic matter was obtained from the difference between the weight of dried and combusted samples. After combustion, only mineral particles remained.

\section{RESULTS}

Five species of snow algae (Chlorophyta and cyanobacteria) were observed on the glacial surface (Fig. 3). Their descriptions are as follows:

\section{Chlorophyta (green algae)}

Chloromonas sp. (Fig. 3a)

Cells round, red orange pigmented. A chloroplast without pyrenoid. Round cells $17.6 \pm 5.7 \mu \mathrm{m}$ (mean $\pm \mathrm{SD}$ ).

\section{Ancylonema nordenskioeldii Berggren (Fig. 3b)}

Filaments straight or slightly curved, consisting of 2-20 cells. Cells $27.2 \pm 4.4 \mu \mathrm{m}$ long, $12.7 \pm 1.1 \mu \mathrm{m}$ wide. Chloroplast with one or two pyrenoids. Cell sap usually dark brown.

Mesotaenium breggrenii (Wittrock) Lagerheim (Fig. 3c) Cells single or paired, cylindrical with rounded apices. One to two chloroplasts, with one pyrenoid. 14.2 $\pm 4.1 \mu \mathrm{m}$ long, $10.7 \pm 1.5 \mu \mathrm{m}$ wide. Cell sap dark brown. 


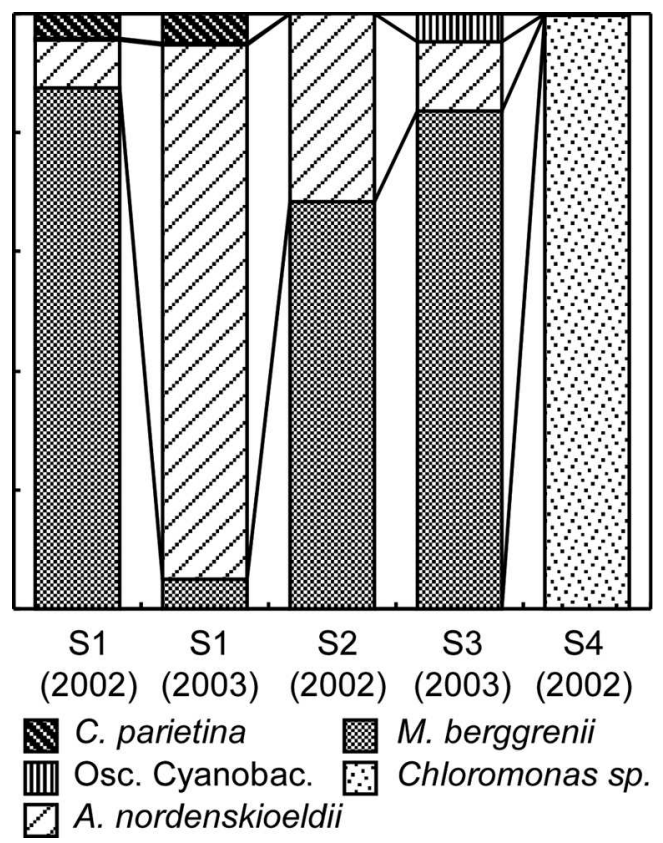

Fig. 5. Variations in community structure of snow algae among collection sites on Akkem glacier (proportion of cell volume biomass).

\section{Cyanobacteria (blue-green algae)}

\section{Oscillatoriaceae cyanobacteria (Fig. 3d)}

Trichomes $1.7 \pm 0.29 \mu \mathrm{m}$ wide, $1.8 \pm 0.45 \mu \mathrm{m}$ long. Cells about 1.5 times longer than wide.

\section{Calothrix parietina Thuret (Fig. 3e)}

Filaments brown, sinuous, often branched, cylindrical, longtapering at the upper end, and $9.0 \pm 1.1 \mu \mathrm{m}$ wide (mean \pm SD). Trichome blue-green or brownish, cylindrical. Heterocysts brownish and spherical.

The total cell-volume biomass of snow algae in the samples ranged from $0.79 \times 10^{3}$ to $2.3 \times 10^{3} \mu \mathrm{L} \mathrm{mL}^{-1}$. The cell concentration ranged from $2.2 \times 10^{2}$ to $1.5 \times 10^{5}$ cells $\mathrm{mL}^{-1}$. The biomass varied among study sites (Fig. 4). The highest biomass occurred in the ice area at site S1 (2003), while the lowest occurred in the snow area at site S4 (2002). A statistical analysis (one-way analysis of variance (ANO$\mathrm{VA})$ ) revealed that the variation in the biomass was significant $(F=4.33, P=0.012<0.05)$.

Our examination of community structure showed that A. nordenskioedii and $M$. breggrenii were the dominant species in the ice area, while Chloromonas sp. was dominant in the snow area (Fig. 5). The former two species accounted for $>95 \%$ of the biomass at all sites in the ice area. Chloromonas sp. was dominant in the snow area, but was not observed at any ice-area site. The two species of cyanobacteria were a rather insignificant presence in the ice area. Oscillatoriaceae cyanobacteria were observed only at site S3, and C. parietina only at site S1.

The amount of cryoconite (per unit area) on the glacial surface ranged from 0.32 to $550 \mathrm{~g} \mathrm{~m}^{-2}$ (mean: $124 \mathrm{~g} \mathrm{~m}^{-2}$ ) in the ice area (Fig. 6). Since the variation in the amount at each study site was large, there was statistically no significant difference in the amounts of cryconite among the sites. The percentage of organic matter in the cryoconite (dry weight) ranged from 2.1 to $9.7 \%$ (mean: $2.9 \%$ ).

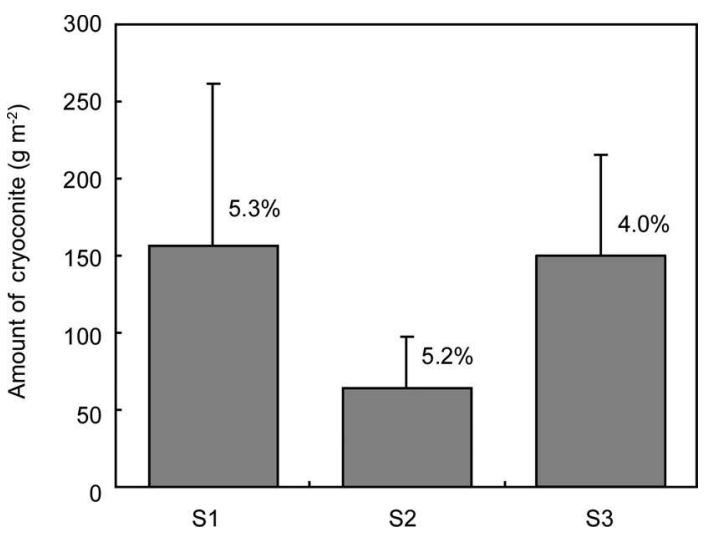

Fig. 6. Amounts of surface dust (cryoconite) on Akkem glacier (in dry weight). Error bars indicate standard deviation. Percentage of organic matter is also shown.

\section{DISCUSSION}

Our results show a flourishing algal community consisting of green algae and cyanobacteria on this Altaic glacier. During our field investigation, collembola (insects) were also observed in the ice area. These heterotrophic organisms are most likely sustained by snow algal primary production, suggesting the existence of an ecosystem based on the primary production of snow algae on the glacier as well as on glaciers in other parts of the world.

The species of snow algae observed on this glacier are commonly found on glaciers in the Northern Hemisphere and elsewhere. For example, $M$. breggrenii is a common species on many of the world's glaciers, reported in the Antarctic, Patagonia, the Himalaya and Alaska (e.g. Kol, 1942; Ling and Seppelt, 1990; Yoshimura and others, 1997; Takeuchi, 2001; Takeuchi and Kohshima, 2004). A. nordenskioeldii is a species often observed on glaciers and sea ice in the Northern Hemisphere (Kol, 1942; Melnikov, 1997; Yoshimura and others, 1997; Takeuchi, 2001; Takeuchi and others, 2001a). A genus of Chloromonas is common on snow surfaces worldwide. The visible red snow phenomenon caused by Chloromonas sp. is especially common in North America (e.g. Hoham and Duval, 2001). C. parietina has been reported on glaciers in Greenland and the Canadian Arctic (Gerdel and Drouet, 1960; Takeuchi and others, 2001a). Although the particular species of Oscillatoriaceae cyanobacterium could not be identified in this study, this family is a very common cyanobacterium on glaciers throughout the world (e.g. Kohshima, 1989; Yoshimura and others, 1997; Takeuchi, 2001; Takeuchi and Kohshima, 2004).

The distribution of each species on Akkem glacier was consistent with the categories of habitats suggested by previous studies. According to Yoshimura and others (1997), the snow algae on glaciers can be classified into four specialized types: snow-environment specialists (observed on the snow surface), ice-environment specialists (observed on bare ice), generalists (observed on both snow and ice) and opportunists (observed on a specific area of the ice or snow surface). A. nordenskioeldii has been categorized as an ice-environment specialist, $M$. berggrenii as an ice-environment specialist or generalist, and Chloromonas sp. as a snow-environment specialist by previous studies (Kol, 1942; Yoshimura and others, 1997; Takeuchi, 2001; 


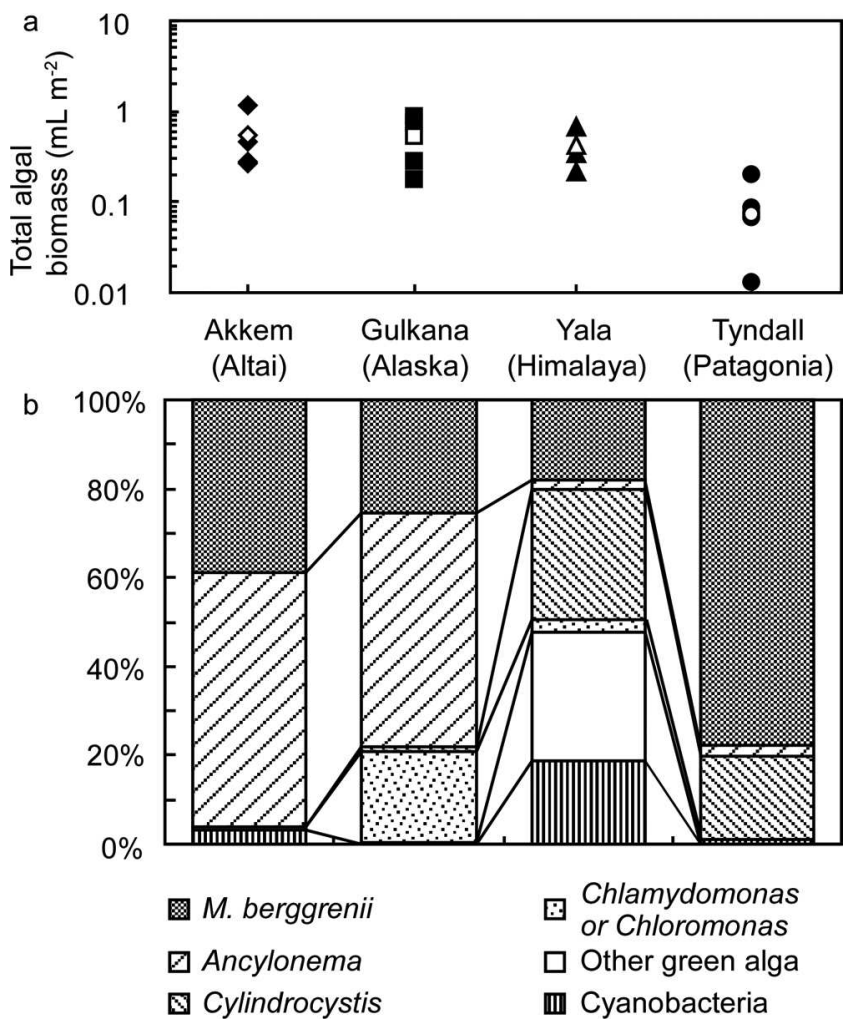

Fig. 7. Comparison of total cell-volume biomass (a) and community structure (b) of snow algae on ice areas among Altaic, Alaskan, Himalayan and Patagonian glaciers. Solid and open symbols in (a) indicate data of separate sites and the mean of the data for each glacier, respectively. Sources of data are Takeuchi (2001) for Alaska, Yoshimura and others (1997) for the Himalaya, and Takeuchi and others (2004) for Patagonia.

Takeuchi and Kohshima, 2004). These categories agree with the distribution of each algal species on this glacier, i.e. $M$. berggrenii and $A$. nordenskioeldii were common on the ice surface, and Chloromonas sp. was found only on the snow surface. The family of Oscillatoriaceae has usually been classified as composed of opportunists or ice-environment specialists (Yoshimura and others, 1997; Takeuchi, 2001; Takeuchi and Kohshima, 2004). Since the Oscillatoriaceae cyanobacterium was observed only at site S3, it could be classed as an opportunist on this glacier. Since $C$. parietina has been reported on ice surfaces or in cryoconite holes (Gerdel and Drouet, 1960; Takeuchi and others, 2001a), it could also be considered to be composed of opportunists or ice-environment specialists. C. parietina was consistently observed at only one site in the ice area, thus qualifying it as an opportunist. The variable conditions of the glacial surface favoring growth of snow algae are likely to explain the differences found in the algal community among sites.

The difference in the algal community at site S1 between 2002 and 2003 may be due to physical conditions on the glacial surface. The biomass at site S1 was higher in 2003 than in 2002, with the dominant species being A. nordenskioeldii in 2003, but M. berggrenii in 2002. The location of the snowline was higher in 2003 than in 2002, indicating warmer summers and/or less winter snow in 2003. These conditions could cause a higher algal biomass since the intensity of solar radiation at the algal habitat (glacial surface) would be high in warmer summers or with less snow cover on the glacial surface. The dominance of
A. nordenskioeldii in 2003 is also probably due to those conditions, which may be favorable to this species.

Compared with the algal communities on glaciers in other parts of the world, the algal biomass on this glacier was greater than that on a Patagonian glacier, but comparable to those on Alaskan and Himalayan glaciers. Figure 7a shows a comparison of algal biomass on the ice surface among the glaciers in the Altai (this study), Himalaya, Alaska and Patagonia. The mean algal biomass on the Altaic glacier was $0.54 \mathrm{~mL} \mathrm{~m}^{-2}$, which is comparable to those on the Alaskan and Himalayan glaciers, i.e. 0.52 and $0.42 \mathrm{~mL} \mathrm{~m}^{-2}$, respectively (Yoshimura and others, 1997; Takeuchi, 2001), but was approximately seven times larger than that on the Patagonian glacier $\left(0.073 \mathrm{~mL} \mathrm{~m}^{-2}\right.$; Takeuchi and Kohshima, 2004).

The community structure on this glacier was similar to that on Alaskan glaciers (Fig. 7b). The two dominant species, M. berggrenii and A. nordenskioeldii, in the ice area of this glacier were similarly dominant in the ice area of Alaskan glaciers (Kol, 1942; Takeuchi, 2001; Takeuchi and others, 2003). For example, they constituted $69-97 \%$ of the total algal biomass in the ice area on Gulkana Glacier in the Alaska Range. In the snow area on the Alaskan glaciers, Chlamydomonas nivalis was dominant. Moreover, this alga caused a significant level of visible red snow on that glacier similar to those observed on the Altaic glacier in this study (Takeuchi, 2001). It is recognized that the genera of Chlamydomonas and Chloromonas are taxonomically very close (Hoham and others, 2002), which may explain why community structures on the snow surface are also similar between Alaskan and Altaic glaciers.

In contrast to Alaskan glaciers, however, the community structures on Himalayan, Patagonian and Tibetan glaciers were different from that on this Altaic glacier (Fig. 7b). On Himalayan glaciers, Cylindrocystis brébissonii was dominant in the ice area (Yoshimura and others, 1997; Takeuchi and others, 1998). Although the algal communities on Himalayan glaciers include $M$. berggrenii and Oscillatoriceae cyanobacterium, the percentages of their dominance ranged from only $10 \%$ to $50 \%$ of the total biomass (Yoshimura and others, 1997). On a Patagonian glacier, $M$. berggrenii was dominant in the ice area. Reports on snow algae on the Tibetan glaciers (the Kunlun Shan and Qilian Shan) have shown that Oscillatoriaceae cyanobacteria are dominant (Kohshima, 1989; Takeuchi and others, 2005).

Our results showed that in terms of community structure, the algal community in this Altaic glacier was more similar to those on Alaskan glaciers rather than those on Himalayan or Tibetan glaciers, even though the Altaic glaciers are geographically much closer to the Himalaya and Tibet than to Alaska. The existence of $C$. parietina, which has been reported only in Greenland and arctic glaciers, suggests a similarity to algal communities on glaciers in the Arctic region. Such a similarity among those algal communities suggests that physical or chemical conditions affecting the species competition are similar among those glaciers, whereas they differ from those in Himalayan and Tibetan glaciers. However, it is uncertain precisely which conditions account for this geographical difference. Abundant amounts of wind-blown dust falling on the glacial surface in the Himalaya and Tibet may be one such condition. Since both those regions are located close to arid deserts, dust deposition is likely to be much higher on these glaciers compared with those in Alaska and the Altai (e.g. Wake and others, 1993). Higher depositions of dust could alter 
chemical conditions on the glacial surface, which may affect the algal community. For example, the $\mathrm{pH}$ for meltwater on Tibetan glaciers is generally higher than on glaciers in other regions including Altai. This study showed that the $\mathrm{pH}$ on Akkem glacier ranged from 2.87 to 5.20 , while the $\mathrm{pH}$ on Tibetan glaciers is usually $>7.0$ due to high dust deposition (e.g. Sheng, 1989). In addition to the effect of dust, a monsoon climate and higher solar radiation due to their lower latitude may cause the difference in algal communities in the Himalaya and Tibet.

In terms of the amount of cryoconite on the glacial surface, the Altaic glacier is also more similar to glaciers in Alaska, but significantly different from those in the Himalaya and Tibet. A comparison of the amounts of cryoconite on the ice surface (Fig. 8) showed that the mean amount on the Altaic glacier was $124 \mathrm{~g} \mathrm{~m}^{-2}$, which was much lower than those on a Himalayan $\left(225 \mathrm{~g} \mathrm{~m}^{-2}\right.$; Takeuchi and others, 2001c) and a Tibetan glacier $\left(292 \mathrm{~g} \mathrm{~m}^{-2}\right.$; Takeuchi and others, 2005), but comparable to those on an Alaskan $\left(23.0 \mathrm{~g} \mathrm{~m}^{-2}\right.$; Takeuchi, 2002) and a Patagonian glacier $\left(38.8 \mathrm{~g} \mathrm{~m}^{-2}\right.$; Takeuchi and others, 2001b). The amount of organic matter in cryoconite on the Altaic glacier $\left(4.1 \mathrm{~g} \mathrm{~m}^{-2}\right)$ was also markedly lower than those on the Himalayan $\left(16.0 \mathrm{~g} \mathrm{~m}^{-2}\right)$ and Tibetan glaciers $\left(25.4 \mathrm{~g} \mathrm{~m}^{-2}\right.$; Fig. 8). The amounts of cryoconite on the glacial surface are important in terms of glacial surface albedo, which is one of the important factors affecting the glacial heat budget and mass balance. Snow algae and cryoconite can reduce the surface albedo, thus accelerating melting on the glacial surface. It has been reported that the effect of cryoconite on surface albedo is particularly significant on the ice surfaces of Himalayan and Tibetan glaciers (Kohshima and others, 1993; Takeuchi and others, 2001c, 2005). However, its effect on this Altaic glacier seems insignificant, with amounts much lower than those on Himalayan and Tibetan glaciers. As suggested by Takeuchi (2002), the lower amounts of cryoconite on this Altaic glacier may be due to a smaller biomass of filamentous cyanobacteria, which have been reported to play an important role in the formation of cryoconite on Himalayan and Tibetan glaciers (Takeuchi and others, 2001c, 2005). They can entangle mineral and organic particles to form a granular algal mat (cryoconite granule), which is a major component of glacial cryoconite. However, since the algal community on this Altaic glacier is dominated by unicellular green algae, it may produce smaller amounts of cryoconite.

Our results suggest that a geographical boundary of algal community structures may exist somewhere between the Altai and the Tibetan Plateau (Fig. 1). Such differences in algal communities are very important not only for the ecology of snow algae but also for our understanding of their biological impact on the surface albedo of glaciers in these regions. Those glaciers may also differ in their glaciological aspects. However, quantitative data on snow algal communities are currently available for only a limited number of glaciers. It will be necessary to collect more extensive data on glaciers in these regions in order to better understand the geographical distribution of snow algal communities.

\section{ACKNOWLEDGEMENTS}

We thank all the members of our expedition: T. Prokopinskaya, A. Lushnikov, A. Chebotarev, A. Surazakov, D. Joswiak, A. Takahashi and T. Yamazaki. We also thank

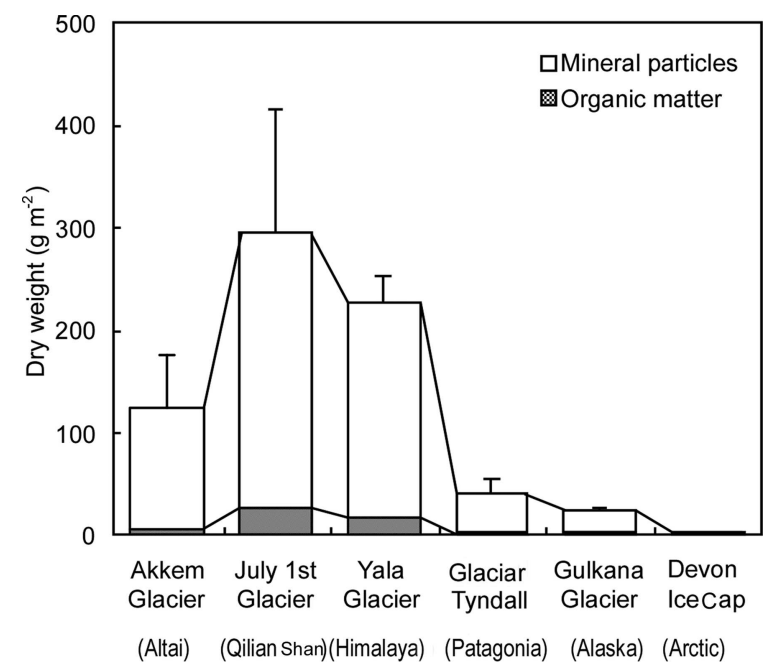

Fig. 8. Comparison of amounts of surface dust (cryoconite) and their components among various glaciers worldwide. Error bars indicate standard deviation. Sources of data are Takeuchi and others (2005) for Tibet, Takeuchi and others (2001c) for the Himalaya, Takeuchi and others (2001b) for Patagonia, Takeuchi (2002) for Alaska, and Takeuchi and others (2001a) for the Arctic.

the two anonymous reviewers for helpful suggestions. This project was supported by the research projects 'Ice core analysis with cryo-microbes on glaciers in a Chinese arid region' and the 'Aeolian Dust Experiment on Climate Impact (ADEC)' financed by the Special Coordination Funds for Promoting Science and Technology of the Ministry of Education, Culture, Sports, Science and Technology of Japan, as well as by the research project 'Historical evolution of adaptability in oases region to water resources changes (Oasis Project)' organized by the Research Institute for Humanity and Nature, Kyoto, Japan. The laboratory analysis was supported by Grants-in-Aid for scientific research (No. 15710018).

\section{REFERENCES}

Christner, B.C., E. Mosley-Thompson, L.G. Thompson and V. Zagorodnov. 2000. Recovery and identification of viable bacteria immured in glacial ice. Icarus, 144(2), 479-485.

Gerdel, R.W. and F. Drouet. 1960. The cryoconite of the Thule area, Greenland. Trans. Am. Microsc. Soc., 79(3), 256-272.

Hoham, R.W. and B. Duval. 2001. Microbial ecology of snow and freshwater ice with emphasis on snow algae. In Jones, H.G., J.W. Pomeroy, D.A. Walker and R.W. Hoham, eds. Snow ecology: an interdisciplinary examination of snow-covered ecosystems. Cambridge, etc., Cambridge University Press, 168-228.

Hoham, R.W., T.A. Bonome, C.W. Martin and J.H. Leebens-Mack. 2002. A combined $18 \mathrm{~S}$ rDNA and rbcL phylogenetic analysis of Chloromonas and Chlamydomonas (Chlorophyceae, Volvocales) emphasizing snow and other cold-temperature habitats. J. Phycol., 38(5), 1051-1064.

Kohshima, S. 1987. Glacial biology and biotic communities. In Kawano, S., J.H. Connell and T. Hidaka, eds. Evolution and coadaptation in biotic communities. Kyoto, Kyoto University. Faculty of Science, 77-92.

Kohshima, S. 1989. Glaciological importance of microorganisms in the surface mud-like materials and dirt layer particles of the Chongce Ice Cap and Gozha Glacier, West Kunlun Mountains, China. Bull. Glaciol. Res., 7, 59-65. 
Kohshima, S. 1994. Environmental changes in the high latitudes glacier ecosystems. Japan. J. Ecol., 44(1), 93-98. [In Japanese.]

Kohshima, S., K. Seko and Y. Yoshimura. 1993. Biotic acceleration of glacier melting in Yala Glacier, Langtang region, Nepal Himalaya. IAHS Publ. 218 (Symposium at Kathmandu 1992 Snow and Glacier Hydrology), 309-316.

Kol, E. 1942. The snow and ice algae of Alaska. Smithsonian Misc. Collect. 101.

Ling, H.U. and R.D. Seppelt. 1990. Snow algae of the Windmill Islands, continental Antarctica. Mesotaenium berggrenii (Zygnematales, Chlorophyta) the alga of grey snow. Antarct. Sci., 2(2), 143-148.

Melnikov, I.A. 1997. The Arctic sea ice ecosystem. Amsterdam, Gordon and Breach.

Reynolds, C.S. 1984. The ecology of freshwater phytoplankton. Cambridge, etc., Cambridge University Press.

Sheng, W. 1989. Hydrogeochemical characteristics in the Gozha Lake area of the West Kunlun Mountains. Bull. Glaciol. Res., 7, 119-122.

Takeuchi, N. 2001. The altitudinal distribution of snow algae on an Alaska glacier (Gulkana Glacier in the Alaska Range). Hydrol. Process., 15(18), 3447-3459.

Takeuchi, N. 2002. Surface albedo and characteristics of cryoconite (biogenic surface dust) on an Alaska glacier, Gulkana Glacier in the Alaska Range. Bull. Glaciol. Res., 19, 63-70.

Takeuchi, N. and S. Kohshima. 2004. A snow algal community on a Patagonian glacier, Tyndall glacier in the Southern Patagonia Icefield. Arct. Antarct. Alp. Res., 36(1), 91-98.

Takeuchi, N., S. Kohshima and K. Fujita. 1998. Snow algae community on a Himalayan glacier, Glacier AX010 East Nepal: relationship with glacier summer mass balance. Bull. Glaciol. Res., 16, 43-50.
Takeuchi, N., S. Kohshima, K. Goto-Azuma and R.M. Koerner. 2001a. Biological characteristics of dark colored material (cryoconite) on Canadian Arctic glaciers (Devon and Penny ice caps). Natl. Inst. Polar Res. Mem. 54, Special Issue, 495-505.

Takeuchi, N., S. Kohshima, T. Shiraiwa and K. Kubota. 2001b. Characteristics of cryoconite (surface dust on glaciers) and surface albedo of a Patagonian glacier, Tyndall Glacier, Southern Patagonia Icefield. Bull. Glaciol. Res., 18, 65-69.

Takeuchi, N., S. Kohshima and K. Seko. 2001c. Structure, formation, and darkening process of albedo-reducing material (cryoconite) on a Himalayan glacier: a granular algal mat growing on the glacier. Arct. Antarct. Alp. Res., 33(2), 115-122.

Takeuchi, N., S. Kohshima and T. Segawa. 2003. Effect of cryoconite and snow algal communities on surface albedo on maritime glaciers in south Alaska. Bull. Glaciol. Res., 20, 21-27.

Takeuchi, N., Y. Matsuda, A. Sakai and K. Fujita. 2005. A large amount of biogenic surface dust (cryoconite) on a glacier in the Qilian Mountains, China. Bull. Glaciol. Res., 22, 1-8.

Thomas, W.H. and B. Duval. 1995. Sierra Nevada, California, U.S.A., snow algae: snow albedo changes, algal-bacterial interrelationships, and ultraviolet radiation effects. Arct. Alp. Res., 27(4), 389-399.

Wake, C.P., P.A. Mayewski, Z. Xie, P. Wang and Z. Li. 1993. Regional distribution of monsoon and desert dust signals record in Asian glaciers. Geophys. Res. Lett., 20(14), 1411-1414.

Yoshimura, Y., S. Kohshima and S. Ohtani. 1997. A community of snow algae on a Himalayan glacier: change of algal biomass and community structure with altitude. Arct. Alp. Res., 29(1), 126-137.

Yoshimura, Y., S. Kohshima, N. Takeuchi, K. Seko and K. Fujita. 2000. Himalayan ice-core dating with snow algae. J. Glaciol. 46(153), 335-340. 